\title{
Çocuk Kitabı Resimlemelerinde Ölüm Kavramı: Kavram Öğretimi ve Resimleme Bağlamında Çocuk Kitabı İncelemeleri
}

Doç. Banu Bulduk Türkmen

\section{Özet}

Okul öncesi dönemdeki çocuklara soyut kavramların öğretilmesi, resimleme alanılla desteklenerek ele alınan bir süreç ile gerçekleştirilir. Bu araştırma makalesinde soyut kavramların tematik olarak işlendiği çocuk kitabı örneklerinden hareketle, özellikle ölüm kavramı, resimlenmiş çocuk kitaplarındaki ele alınış biçimleri, yöntem, içerik ve resimlemelerinin incelenmesiyle temellenir. Bu çallşmanı yöntemi, soyut kavramlardan ölüm kavramının çocuk kitaplarında ele alıış biçimlerinin kavramsal vurgu, anlamsal yorumlama, biçimsel yapıda resimleme açııından incelenmesini esas alır. Kavramın öğretilmesine yönelik materyallerin hazırlanması, doğru içerik ve yaklaşımla öğretim sürecinin yaşanması ve çocuk kitaplarındaki kavram temelli yaklaşımlar makalenin bassıco sorunsalıdır. Kavram öğretimi stratejisi çerçevesinde aşamalar, kitap tasarımı ilkeleri kapsamında iç yapı ve dıs yapı bağlamında içerik ve resimleme ilişkileri, resimlemelerde biçim ve içerik özellikleri temel alınarak incelenmisstir. Inceleme ve değerlendirme yönteminde nitel araștırma ekseninde veri toplanarak döküman analizi yapılmaktadır. Örnek incelemeleri belirlenen kavram çerçevesinde olușturulmakta, amaçsal örneklendirme yapılmakta, şocuğ görelik yaklaşııııla değerlendirmekte ve resimlemelerin geliştirilmesi sürecinde söz konusu tasarım biççm-içerik ilişkisi göz önünde bulundurularak sonuçlandırılmaktadır.

Anahtar Kelimeler: Çocuk Kitabı Resimlemesi, Ölüm Kavramı, Çocuk Kitaplarında Iç̧erik ve Biçim lilişisi, Resimleme, Kavram Öğretimi.

THE CONCEPT OF DEATH IN CHILDREN'S BOOK ILLUSTRATION: CONCEPT TEACHING AND CHILDREN'S BOOK STUDIES IN THE CONTEXT OF ILLUSTRATION

\section{Abstract}

Teaching abstract concepts to preschool children is carried out with a process that is supported by the field of illustration. In this research article, especially the concept of death, is grounded on the examination of the way it is approached in illustrated children's books, methods, content and illustrations regarding the examples of children's books in which abstract concepts are thematically studied. The method of this study is based on examining how the concept of death, which is one of the abstract concepts, is handled in children's books, in terms of conceptual emphasis, semantic interpretation, and illustrating in formal structure. The main problems of the article are preparing materials for teaching the concept, experiencing the teaching process with the right content and preparing materials for teaching the concept, experiencing the teaching process with the right content and
approach, and concept-based approaches in children's books. Within the framework of concept teaching strategythe stages are examined based on the content and illustration relations in the context of internal and external structure within the scope of book design principles. form and content features in illustrations. In the examination structure within the scope of book design principles, form and content features in illustrations. In the examination
and evaluation method, document analysis is performed by collecting data based on qualitative research. Sample and evaluation method, document analysis is performed by collecting data based on qualitative research. Sample studies are created within the framework of the determined concept, purposive sampling is made and evaluated
with a child relativity approach and in the process of developing illustrations, it is concluded by considering the with a child relativity approach and in
relationship between form and content.

Keywords: Illustration of Children's Book, The Concept of Death, The Relationship Between Content and Form in Children's Books Illustration, Concept Teaching. 


\section{Giriş}

Çocuklara, bebeklikten yetişkin bir birey olma sürecine değin kitap okumanın belirli bir zamanı, yeri ve kuralı olmamıştır. Çocuğa kitap okumak ya da çocukla beraber kitap okumak, çocuk ve ebeveyin arasında gelişen iletişimin ve bağın en sağlıklı kurulduğu bir etkinlik olarak değerlendirilir Öyle ki bebekler, çevreyi, doğayı, dili çocuk kitapları ve resimlemeleri aracılığı ile daha kolay öğrenirler. Yükselen (2019: 57), bu dönemde resimli çocuk kitaplarının çocuk gelişime etkilerini sıralarken; özellikle okul öncesi dönemdeki çocukların dil gelişimini desteklediğinden, kendisini tanımasına ortam sağladığından, toplumsallaşmasına yardımcı olduğundan, sanatsal ve kültürel değerler kazandırdı̆̆ından söz eder. Yaş gruplarının bedensel ve zihinsel gelişimleri göz önünde bulundurularak resimli çocuk kitaplarında konular belirlenir. Örneğin, 0-3 yas çocuklarında çevresini tanıma isteklerini destekleyici temel (somut) kavram kitapları, dil gelişim hızlarını destekleyici tekrarlı sözcüklerin kullanımı, yeni kelimelerin betimlendiğ sözcük kitapları tasarlanmaktadır. Bu dönemde bireysel olarak yürüme, koşma, yemek yeme gibi eylemlerini tanımlayan resimlemeler de, çocuğun çevresini ve kendisini keşfetmesine katkı sunmaktadır. 3-4 yaş aras çocuklarda ise, kelimeleri birleşik tümce kuracak şekilde kullanma becerisi gelismekte, zaman kavramı oluşmakta, kitaplardaki resimlemeleri yorumlayabilmekte böylelikle de dili etkin kullanarak ifade becerileri gelişmektedir. Duygusal yönden birbirleriyle de iletişim kurabilen bu yaş aralı̆̆ındaki çocuklar, duygu anlatan kitaplarla tanışırlar. 4-6 yaş aralığındaki çocuklar ise, artık dil becerileri gelişmekte, harfleri tanıyabilmekte, resimli kitaplarda metinlere de dikkat etmektedir. 7-9 yas arası okul dönemi olarak tanımlanan çocuklar, artık kitapları kendi başlarına okuyarak okuma eylemini eğlenceli bir etkinlik haline getirmektedir. Metinlerin anlamını kavramakta, okudukça konuşma dilindeki sözcük dağarcılığı zenginleşmektedir. Yapılan araştırmalar, resimli çocuk kitaplarının çocukların okuma yazma gelişimini de olumlu etkilediği yönündedir. Kavram gelişiminin hızlı olduğu bu dönemdeki çocuklar renk, büyüklük ve biçim arasında ilişki kurabildikleri, bu nedenle kavram kitaplarının bu dönemdeki çocuklarla tanıştıııması ifade edilir (Yükselen, 2019: 62). Sosyal farkındalık ve soyut kavramlar da keza çocukların anlamlandırmada zorlandıkları bir evreyi temsil eder. Bu aşamada çocuk pedagogları, eğitim psikologları, yayınevleri ve çocuk illüstratörleri bir araya gelerek, anlamlandırma bağlamında hayatta karşılaştıkları ayrıık, ölüm, veda, boşanma, yalnızlık, iyilik, arkadaşlık, yardımseverlik vb. soyut kavramları tematik bir şekilde işledikleri kitap tasarlama yoluna giderler. Bu kavramlardan birisi olan ölüm kavramı, bu araştırma kapsamında ele alınmaktadır.

\section{Yöntem}

Makale kapsamında ele alınan konu, okul öncesi dönemde çocuklara yönelik resimli öykü kitaplarında soyut kavramların anlatılmasına yönelik kitap incelemesi yapılmasıdır. Çocuklara kavram öğretimini temel alan, sanat ürünü / edebiyat ürünü olarak doğrudan eğitim amacı olmayan, dolaylı yoldan bu sürece katkı sağlayan çocuk kitapları ele alınmaktadır. Kavram olgusunun anlaşılmasını sağlayacak betimlemelerle doğrudan kaynak üzerinden inceleme yapılmakta, kuramsal, biçimsel ve tasarım yönü göz önünde bulundurularak değerlendirme yapılmaktadır.Bu çalışmanın yöntemi, soyut kavramlardan ölüm kavramının çocuk kitaplarında ele alınış biçimlerinin kavramsal vurgu, anlamsal yorumlama ve biçimsel yapı kapsamında resimlemelerinin incelenmesidir. İnceleme ve değerlendirme yönteminde nitel araştırma ekseninde veri toplanarak dökuman analizi yapılmaktadır.

Anlatılması ve algılanması zor olarak nitelendirilen soyut kavramlardan ölüm kavramını tematik olarak işlemiş resimli çocuk kitaplarından örnekler belirlenmiş, amaca uygun örnekleme yapılmıs, gösteren ve gösterilen ilișkisi bağlamında tematik kavramın hikayeleştirilmesi, karakterize edilmesi ve resimlemelerdeki biçim ve teknik, çocuğa görelik kavramı doğrultusunda hedef kitlesinin yaş aralığına uygunluğu açısından değerlendirilmektedir. Ülgen(2001: 111), bireylerde kavram öğrenme yönteminin iki aşamada gerçekleştiğinden söz eder. Bunlar, kavram oluşturma ve kavram kazanma aşamalarıdır. Kavramların gelişmesi ise "bireyin oluşturduğu ya da kazandığı kavramın nitelik açısından olumlu yönde artış kaydetmesine ișaret eder" Ülgen(2001: 122), kavram geliştirmede stratejik bilgilerin çocukların farklı yaşlarda farklı strateji geliştirmesiyle kazanıldığını söylemekte, Hulse, Deese ve Egeth (1975) ise, mantıksal strateji bağlamında kavram öğrenmenin belirli bir sırası olduğunu ifade etmektedir.

1. Kavramın özelliklerini algılama (Kavramın orjinalini/prototype oluşturma).

2. Bu özellikleri kavram öğrenme tecrübesinde uyarıcılara kodlama.

3. Objeleri, kavramların çeşitlerine göre kodlama.

4. Tecrübelerin artmasıyla, dünyadaki bilgilerin sınıflara bölündüğünü anlama ve onları öğrenmek için, çeşitli mantıksal kuralları sistematik olarak kullanma (Akt: Ülgen, 2001: 123).

Bireylerin bu düzen içerisinde bir strateji geliştirmesinin olası olduğundan bahsedilirken, bu araştırma makalesi kapsamında örnek incelemeleri yapılırken, kavramsal öğrenme deneyiminin mantıksal sıralaması da göz önünde tutulmaktadır. Makalede araştırma ve yayın etiğine uyulmakta, 
ayrıca etik kurul kararı gerekmemektedir.

\section{Kavram ve İletişim}

İletişimde etkin olarak kullandığımız sözlü yöntem, içerisinde kavramlar barındıran bir olgudur. Kavramların anlamları bu sürecin tanımını iletişim olarak belirler. İletişimin anlamlı olması ve anlam içermesi özelliği bu bağlamda devreye girer. Duygu, düşünce ve bilgi iletimi, iletişim süreci içerisinde gerçekleşir. İletişimin anlamlı gerçekleştirilmesi, iletinin anlaşılıp tepki ve tepkisizlik gibi etki göstermesi ile yaşanır. Gösteren ve gösterilen bağlamında algılanabilen her türlü gerçeklik, iletişim görevi üstlenir. Gösterenin yalnızca duyusal nitelikte olmaması, soyut bir kavramın da bir gösteren olarak değerlendirilmesine olanak tanır (Guiraud, 2016: 10). Aktarılan bir görüntüyü, iletiyi, bilgiyi, düşünceyi görünür formda anlamlandırabilmek, biçim görüntüsünün işlenişi ile paralel olarak gelişir. Keza iletişimde işitsel yöntemde de bilinen ve öncesinde öğrenilen bilgiler kavramları tanımlayabilmek/anlamlandırabilmek için gerekli olmaktadır. Anlamlandırma kavramını göstergebilimsel açıdan tanımlamak gerekirse; "okuyucunun, izleyicinin ya da dinleyicinin, duyu organlarına sunulan konuyu, kültürel birikimi, düşünsel yeteneği, algı biçimi gibi etkenlerinin toplamı ile algılanmasını ve bu doğrultuda ulaştığı anlamı" olarak tanımlamak mümküdür (Ertan ve Sansarcı, 2016: 27). Kavramların anlamlarının doğru anlaşıması belli bir bilgi birikimi ile gerçekleşmektedir. Öğrenme deneyimi kuramlarında da konunun öğrenilmesini kolay hale getirmek, söz konusu kültürel alt yapının varlığı ile ilişkilendirilmiștir. Cüceloğlu, algılama konusunda "insanoğlunun ancak algıladığı olaylara anlam verebilir" sözüyle kişi için yalnızca algılanan şeyin anlamı olduğunu ifade eder (Cüceloğlu, 2002: 32). Kişiler arası iletişimde de anlam alışverişinin olduğu her durumda iletişimin gerçekleştiği ifade edilebilir. Cüceloğlu'nun(2002: 45), iletişimianlam alışverişi olarak tanımlaması bu duruma örnek gösterilebilir.

Kavram kelimesinin tanımını yapmak gerekirse; " aralarında belirli özellikleri paylaşan bir grup nesne veya olaya verilen semboldür" ifadesi dikkat çeker (Cüceloğlu, 2013: 215). Ülgen'e(2001: 100)göre ise kavram, “insan zihninde anlamlanan, farklı obje ve olgularındeğişebilen ortak özelliklerini temsil eden bir bilgi formu/yapısıdır, bir değişkendir; bir sözcükle ifade edilir." Kavramların nesneyi temsiliyetleri somut olma özellikleriyle ilişkilendirilebilir. Kişilerin doğayı algılama, kavrama, yorumlama becerileri, nesnelerin anlamlarının ya da kavramların birbiriyle ilişkilerinin sağlanması ile kazanılır. Bu bağlamda kavram, düşünce evresinde birden fazla nesnenin iliški kurmasını ve ortak bir çatı altında anlamlı bir bütün sağlamasını gerçekleştirmektedir. Diğer yandan kavramların öğrenilmesi aşamasında dilin içerisindeki kavramların insan düşüncesini etkilemede etken olduğu bilinir. Dil kullanımı kavramların algılanmasını ve ifade edilmesini sağlarken, birbirleriyle ilişkili kavramları ister istemez bir araya getirmektedir. Öyle ki dil, kavram ve algı kavramlarının birbirleriyle sıkı ilişki içerisinde olduğu bir gerçektir.

Iletişimde iletilerin kodlanması, "kısa, çarpıcı, dikkat çekici, akılda kalıcı" olma özellikleri ile iletinin hedef kitle tarafından anlamlanması ve algılanmasını sağlamaktadır (Oskay, 2001: 13). Dil kullanımı, zihinde kavramlar biçimlendiren etkendir. Hoimar von Dithfurth, üç temel biyolojik etkinlik olarak ifade ettiği ayırt etme, tanıyıp öğrenme ve ayıklayıp seçme etkinlikleri ile her türden canlının dış dünya karşısında yaşamını sürdürebildiğini ifade eder(Karataş Coşkun, 2011: 6). Kavramların öğrenimi gerçekleşirken özellikle bu üç temel etkinliklerin deneyimlenir. Zihinde gerçeklestirilen öğrenme deneyimi, öncelikle kavramların anlamını duyusal belleği ile ayırt eder, daha önce gördüğü bir biçim ise hafıza kaydı ile örtüştürerek somutlaştırır ve anlamsal yakınlık kurduğu farklı kavramlarla bir gruba alır. Bu süreç kişinin algılama, seçme ve öğrenme deneyimini de etkiler. Kavramların kişi üzerindeki etkilerini değerlendirmek gerekirse; bireylerin nesneleri sınıflandırmalarını kolaylaştırdıkları, birbirleriyle ilişki kurmalarını sağladıkları ve düşünme becerilerini zenginleştirdiklerinden söz edilmektedir. Özellikle çocuk kitabı resimlemelerinde yaş aralıkları farklılıkları, aynı kavramı öğrenmelerinde süreci farklılaştırmaktadır. Soyut kavramların anlatılması, somutlaştırılması ve tanımlanması çocukların yaşlarına göre zor ya da daha kolay olmaktadır. Bu noktada resimlemelerin görsel algıyı oluşturmada etkin bir rol üstlendiğini söylemek yanlış olmaz.

Resimlemelerde kullanılan kavram temalı içeriklerin değerlendirilmesi, bi diğer bölümde ele alınmaktadır. Resimlemelerde çocukların fiziksel ve bilişsel gelişim süreleri kavram öğrenimini doğrudan etkiler. Bu nedenle çocuklarda bilişsel gelişim süreci ve anadili gelişimine değinilmektedir.

\section{1. Çocuklarda Bilişsel Gelişim Süreci, Anadili Gelişimi ve Kavram Öğrenimi}

Bireylerin gelişim sürecine bilişsel gelişim bağlamında yer vermek gerekirse; Senemoğlu (2018: 34) bilişsel gelişimi “....bebeklikten yetişkinliğe kadar, bireyin çevreyi, dünyayı anlama yollarının daha kompleks ve etkili hale gelmesi" olarak tanımlamaktadır. Piaget'in Bilişsel Gelişim Kuramı'na göre, Bilişsel Gelişimi etkileyen faktörler, olgunlaşma, yaşantı, uyum, örgütleme ve dengeleme olarak sıralanır. Kuramın temel kavramlarına yer vermek gerekirse, zeka, şema, uyum ve dengeleme gelişim sürecini etkileyen etkenlerdir (Akt: Senemoğlu, 2018: 34). Piaget'ye göre bilişsel gelişim, dört 
temel aşamada yaşanır. 0-2 yaş grubu içine alan Duyusal Motor Dönemi, 2-7 yaş sembolik ve sezgisel dönemi içine alan İşlem Öncesi Dönem, 7-11 yaş Somut Iş̧lemler Dönemi ve 11 yaş ve üzeri Soyut iş̧lemler Dönemidir. Her bir aşamada olan çocuğun kavram öğrenimi hızı ve etkinliği farklı olmakta, resimli kitaplar bu aşamalar dikkat edilerek tasarlanmaktadır.

Çoçukların gelişim evreleri, gelişim özelliklerine göre tasarlanan kitaplar ile hem dil gelişimi desteklenmekte hem de zihinde anlamsal kavrama sağlanmaktadır. Çocukların kavramsal gelişmeleri, çocuk belleğinde biriktirdiği imgeler, kitap resimlemeleri ile pekiştirilmektedir. Bilişsel gelişim kuramını araştıran bir diğer araştırmacı ise Jerome Bruner'dir. Bruner, bilişsel gelişimde dil kavramının önemli bir nokta olduğunu ifade eder. Bireylerin dil aracılığı ile kavramları öğrendiklerini belirtir. Öğretici ve öğrenici etkileşiminin bilişsel gelişim için gerekli olduğunu, “...baba, anne, öğretmen ve toplumun diğer üyeleri çocuğa öğretmelidir. Sadece bir kültür içinde doğmak, tam bir bilişsel gelişim için yeterli değildir." (Akt: Senemoğlu, 2018: 57) ifadesiyle öğreticiler olarak tanımladıkları ebeveyin ve dış kaynakların bu konuda önemli olduğunu, çocuk kitaplarının da bir kaynak ve öğreti olarak önem taşıdığını vurgulamaktadır. Bruner ise bilişsel gelişim dönemini üç başlık altında ele alır. 0-3 yaş aralığındaki çocukları kapsayan ve ilk aşama olan Eylemsel Dönem, ikinci düzeyi tanımlayan İmgesel Dönem ve sonuncu düzey olan Sembolik Dönem, çocukların algı düzeylerinin değişimlerini inceleyen aşamalar olarak sıralanmaktadır. Kavramların bireylerin dış dünyayı tanıyıp anlamlandırabilmelerini sağlayan zihinsel bir olgu olduğundan söz edilmişti. Senemoğlu'na (2018: 516-517) göre, bilişsel gelişim kavram öğrenmeyle temellenir. Bireylerde çeşitli düzeylerde gelişme gösteren bu süreç, dört aşamalı bir düzey olarak tanımlanır. Somut düzey, tanıma düzeyi, sınıflama düzeyi ve soyut düzey, söz konusu kavram düzeyleridir. Somut düzey olarak tanımlanan ilk aşamada birey objeyi diğer objelerden ayırabilmekte, objenin çevresine dikkat ederek algılanabililiğini fark etmekte, ayırt edebilmekte, bir başka zamanda da aynı objeyi gördügünde hatıllamaktadır. Tanıma düzeyinde ise, çocuk sadece aynı kapsam ve zamanda objeyi gördüğünde tanıyabilmekte, bu nedenle de objenin algılanabilen ortamı hakkında farkındalık kazanmakta, ayırt ettiği objeyi hatırlamakta, başka zamanda ve ortamda gördüğünde de aynı obje olduğuna ilişkin olarak genelleme yapabilmektedir. Sınıflama düzeyinde olan çocuğun ise iki ya da ikiden fazla objenin belirgin olmayan özelliklerine de dikkat etmesi, ayırt etmesi, hatırlayabilmesine ek olarak eşdeğer olduğuna ilişkin genelleme yapabilmesi belirtilir.

Kavram öğretimi aşamasında, çocukların yaş gruplarına göre somut ve somut kavramları öğrenme zamanları değişebilmektedir. Somut kavramlar, zihinsel gelişim süreci içerisinde çocuklarda sınıflama düzeyi aşamasında öğrenilirken, soyut kavramlar daha ileriki zamanda soyut düzey aşamasında öğrenilmektedir. Araştırmalardan elde edilen bir diğer sonuçta somut kavramların öğrenilmesi soyut kavramların öğrenilmesinden daha az zaman almaktadır (Senemoğlu, 2018: 525). Kavramların öğretimiyle ilgili Klausmeier'in 1985 basım tarihli Eğitim Psikolojisi adlı kitabında yedi temel ilkeden söz eder:

1. Öğrencileri kavram öğrenmeye hazırlama,

2. Kavramın örneklerini ve örnek olmayanları belirleyebilmeleri için strateji kazanmalarına yardım etme,

3. Öğrencilerin kavramların adlarını ve özelliklerini kazanmalarına yardım etme,

4. Öğrencilerin kavramların adlarını ve özelliklerini kazanmalarına yardım etme,

5. Öğrencilerin kavramları tam anlamalarına yardım etme,

6. Öğrencilerin kavramları kullanmalarını sağlama,

7. Öğrencilere dönüt verme (Akt: Senemoğlu, 2018: 531).

Yine Klausmeier'e göre kavram öğretimi yedi aşamada gerçekleşmektedir:

1. İlk aşamada öğrenciye kavramın bütünlük içindeki yeri gösterilmelidir.

2. İkinci aşamada, kavram kendi içinde tanımlanmalıdır.

3. Üçüncü aşamada, kritik özelliklerle değişebilen özellikler belirlenmelidir.

4. Dördüncü așamada, olumlu örneklerle olumsuz örnekler karșılaștırılmalıdır (Bu karşılaştırma Tennson'un ifade etiği gibi, öğrencinin kavramla ilgili edindiği bilgilerin doğruluğunu denetlemek içindir).

5. Beşinci aşamada, kavramın gruplanmasında kullanılacak ölçüt niteliğindeki ilkeler belirlenmelidir.

6. Altıncı aşamada, kavramı kullanarak problem çözme denemeleri yapılmalıdır.

7. Yedinci aşamada, kavramın kapsamına giren özelliklerin bir listesinin yapılmas yararlı görülmektedir (Ülgen, 2001: 133, 134).

Bu bağlamda, kavram öğretimi çocukların zihinsel ve sinirsel gelişiminin belirli bir olgunluğa erişiminden sonra destek kaynaklar ile pekiştirilerek deneyimlenmesiyle yaşanmaktadır. Çocuklar için resimli öykü kitaplarının dil gelişimlerine, sosyal gelişimlerine, duygusal ve bilişsel gelişimlerine yaptığı 
katkı yadsınamaz bir gerçektir. Örnek değerlendirmelerinde Klausmeier'in yedi ilkesinden faydalanılmaktadır.

\section{2. Çocuk Kitaplarında Çocuğa Görelik Kavramı, Tasarım ilkeleri ve Resimleme}

Çocuk kitaplarında tasarım, içerik, biçim, hikaye oluşturma ve resimleme bir bütün olarak değerlendirildiğinde, bir ürünü temsil eder. Kitabın biçimsel özellikleri, içerik özellikleri ve eğitsel özellikleri göz önünde tutularak değerlendirildiğinde çocuğa göre kavramı üzerinde konuşulabilir. Öyle ki Çer, çocuğa göre olan bir kitabın oluşturulmasında dikkat edilmesi gereken ilkeleri şu şekilde ifade etmiştir:

1. Çocuğun doğasının, bakış açıııın, ilgi ve gereksinmesinin, dil ve anlam evreninin ve algılama düzeyinin kitaba yansıması gerekir.

2. Kitabın içerik, biçimsel ve eğitsel özelliklerinin çocuk gerçekliğine uygun olmas gerekir.

3. Kitabın yazın olma ilkelerini göz önünde bulundurması gerekir.

4. Yazar ve çizer, bu gerçekliğin bilinciyle görsel dilin ve sözcüklerin olanaklarıyla ortak bir anlam evreni oluşturmalıdır.

5. Yetişkin bakış açısının ve düşünsel anlayışının çocuk kitaplarına yansımamas gerekir (Çer, 2016: 86).

Çocuklar için kitap, ilk tanıştıklarında oyun nesnesi olarak yer bulabilmekte, ileriki yaşlarında ise iletişim kurabildiği, eğitsel ve öğretici bir materyal olarak bir yakınlık kurabildikleri bir nesneye dönüşmektedir. Çocukların zihinsel farkındalıklarının, ilgi ve eğilimlerinin, öğrenme düzeyleri ve duyusal ve duygusal gelişimlerinin göz önünde tutularak biçim olarak tasarım ve resimlemelerin içerik olarak ise temanın, konunun ve kavramın ele alış şeklinin tasarlanması dikkat edilmesi gereken ayrıntılardır.

Bu makale kapsamında tematik olarak işlenen ölüm kavramını anlatan çocuk kitaplarının değerlendirilme yöntemi, tasarım ilkeleri bağlamında resimleme ve içerik bütünlüğ̈̈, kitabın fiziksel özelliğinin değerlendirilmesi, kolay taşınabilirlik, dayanıkııık, kapak tasarımında ilgi çekicilik, yeterli ve tanıtıcı metinlere yer verilmesi, sayfa tasarımlarındaki devamlılık, resimlemelerde anlamlı metinlerin ve resimlemelerin bir arada kullanımı, yazı karakteri seçimi ve büyüklüklerinin yaş aralığına uygun tasarlanması, kapakta olması gereken bilgilerin göstergebilimsel açıdan yorumlanması vb. özellikler değerlendirilmektedir. Kavram öğretme stratejisi gereği, kavram öğretiminde öğreten rolündeki kişinin kavramı aktarmada izlediği sıralamaya da değinilmektedir. Pragmatik anlamda konuda anlatılmak istenen mesajın çocuğa iletilebilirliği, açıklılığı ve anlaşııırlığı da incelenmektedir. Bu doğrultuda söz konusu kavramın çocuk kitabı resimlemelerinde ele alınışı çocuğa görelik çerçevesinde yorumlanmaktadır.

Çocuk kitabı tasarımına biçimsel yönden bakmak gerekirse, sayfa boyutunun çocuğun yaş aralığına göre planlanıp belirlenmesi, sayfa düzeninin resimleme ve tipografi ile bütün olarak değerlendirilip yerlestirilmesi, kullanılan yazı karakteri seçimi ve resimleme ile ilişkisinin kurulması, görsel öge olan resimlemelerin sayfa tasarımındaki ve hikaye anlatımındaki yeri, içeriğe göre sanatçının renk paletinin geliştirilmesi gibi özellikler tasarım açısından dikkat edilmesi gereken özelliklerdir. Söz konusu özellikler gerek tasarımcı ve resimleyen sanatçıya kolaylık sağlarken, okuyucunun etkili bir öğrenme deneyimi yaşamasııı da sağlar.

Tasarımın bir ögesi olarak resimleme Alan Male'ye (2017: 119). göre" ... görsel sanatlar ve iletişim alanında bilgiyi açıklayan veya aydınlatan tek disiplindir. Bu bağlamsal alan aracılığılla görülenlerin çoğu, yeni bilginin yaratılması ve yorumlanmasıdır." Öyle ki kavramların resimlenmesi, görülmeyen ve elle tutulmayan anlamların anlaşılır olmasını sağlamaktadır. Resimlemeler, hikayenin akışı ve anlaşılırlığını destekleyici imgeler ve görüntülerle konuyu anlatmakta, çok yönlü düșünmeye yönlendirmekte ve açıklayııılığını arttırmaktadır. Bu nedenle eğitim aracı olarak da kullanılan bir disiplin olmakta, bilginin görsel yolla daha kolay anlassılır olmasını sağlamaktadır. Çok kitaplarında resimlemelerin metin ile uyumlu olup olmadığının değerlendirilmesi, çocuğun yaş aralığına uygunluğunun ölçülmesi ve kavramsal temanın resimleme ile anlatımının etkili ve sağlıklı sonuçlandırıp sonuçlandırılmadığının değerlendirmesi gerekmektedir. Değerlendirmeyi yapan kişiler, eğitim psikologları, pedagoglar, yayıncıların, illüstratörler ve tasarımcıların oluştuğu uzman bir ekipten oluşmalıdır. İçerik, tasarım ve uygulama süreci, söz konusu farklı alan uzmanlarının denetiminden geçtiği sürece hatasıza yakın olabilir.

\section{4. Çocuk Kitabı Resimlemelerinde Kavram Anlatımı ve Soyut Kavram- ların İşlenişi}

Resimleme (illüstrasyon) kavramı, bir içeriği, durumu, olayı ya da hikayeyi daha anlaşılır kılmak, aydınlatmak ve açıklamak için yapılan çizimler olarak tanımlanabilir. Çocuk kitaplarında bulunan resimlemelerin yazılı metinleri çocuk zihninde gözle görünür hale getirme ve metni yorumlayabilmesine aracı olmakta etkin rolleri vardır. Hikayeyi öncelikle resimlemeler ile okuyan çocuk, çizerin hayal dünyası ve yorumlama yeteneği ile öğrenme 
deneyimi yaşar. Çocuğun hayal dünyasına katkı sunabilen illüstrasyonlar çocuğun öğrenme hızını olumlu yönde etkilemektedir. Bu doğrultuda çocuk kitabı illüstratörü ve öğretim üyesi Prof. Nazan Erkmen kitaplarda fotoğraf kullanımı ile illüstrasyon kullanımının farkını şu şekilde ifade etmiştir: "Çocuklar fotoğrafta gördüklerinden çok daha düşsel bir dünyada yaşamaktadırlar ve fantezilerini geliştiren resimlemeler gördükçe, daha yaratıcı olurlar" (Erkmen, 1996: 43). Metin ile görsel arasındaki ayrılmaz bütünlüğü illüstrasyon olarak tanımlayan Erkmen,düşsel bir yorumlama ile hayal güçlerini destekleyen illüstrasyonların, çocuk kitaplarında aranan niteliklerden birisi olarak sayıldığını da ifade eder. Resimlemelerin nitelik yönünden değerlendirilmesi söz konusu olursa; içerik ile bütünlüğü, metni tanımlama, açıklayabilme yeterliliği, gerek teknik kullanımı gerek görsel biçimlerin oluşturulması açısından hedef kitlenin yaş aralığına uygunluğu adı geçen nitelikler olarak sıralanabilir.

Okul öncesi dönem için kavranılması, ebeveyn için de anlatılması zor olan belli kavramların çocuk kitaplarında ele alınması rastlanır bir durum olmaktadır. Öyle ki kavramlar, somut ve soyut kavramlar olarak iki başlık altında incelenebilir. Somut kavramlar, duyu organlarımızla algılanabilen, sınıflandırılabilen türde olmakta, bu nedenle dış dünya ile bağlantı kuran bireyler kavramın anlamını gördüğüyle, bildiğiyle ve işittiğiyle örtüştürerek kavrayabilmektedir. Somut kavramların, zihinde belirli bir şekle oturup bir gruba dahil olabilmesi, farklı kavramlar ile anlamları örtüştürebilmesi sebebiyle soyut kavrama göre öğrenilmesinin daha kolay olduğu ifade edilir. Soyut kavramlar ise, somut kavramların kullanılması ile öğrenilebilir. Bir olayı, durumu, oluşu, hissi aktarmak için nasıl ki kişiler somut kavramlar ile görsel bir harita oluşturarak algı deneyimi yaşıyorlarsa, soyut kavramları anlatmak için de somut göstergelerden yararlanıldığı bir gerçektir. Özellikle çocuk kitaplarında çocukların temel ihtiyaç gereksinimlerini karşılayan temel kavram kitapları tasarlanmaktadır. Bu kitaplar aracılığı ile çocuk rakam, şekil, renk, nesne, bitki vb. somut belki de ilk kez karşılaşıtıları kavramları tanıyıp öğrenebilmektedir. Eşleştirme, sınıflandırma, parçalama, birleştirme ve sıraya koyma gibi becerileri kavramaları, söz konusu kitaplar ile pekiștirilir. Bunların yanı sıra mutluluk, arkadaşlık, yardımlaşma, yalnızık, üzüntü, ayrılık, umut, iyilik, paylaşma, ölüm vb. soyut kavramları okul öncesi dönemde çocuklara anlatabilmek, öğrenmelerini sağlayabilmek için görsel öge olan resimlemeden faydalanılması önemlidir. Bu çalışma kapsamında soyut kavramların çocuk kitabı resimlemelerinde ele alınıs ş şekillerine değinilmekte ve özellikle ölüm kavramı ile ilgili resimli öykü kitaplarından örnekler incelenmektedir. Ortak bir tema belirlenen bu kitaplarda, resimlemelerin çocukların kavrama becerilerine etkileri değerlendirilmektedir. Bunun yanı sıra ölüm kavramı dışında soyut kavramları tematik olarak işleyen çocuk kitabı örnekleri seçilmiş ve yer verişmiştir. Bunlardan birisi Görsel 1'de yer alan Dilek Ağacı / The Wish Tree, Kyo Maclear tarafından kaleme alınmış, Chris Turnham tarafından resimlenmiş, Redhouse Kidz Yayınları tarafından basılmıs, 22 × 25,5 cm ebatlı bir resimli öykü kitabıdır.
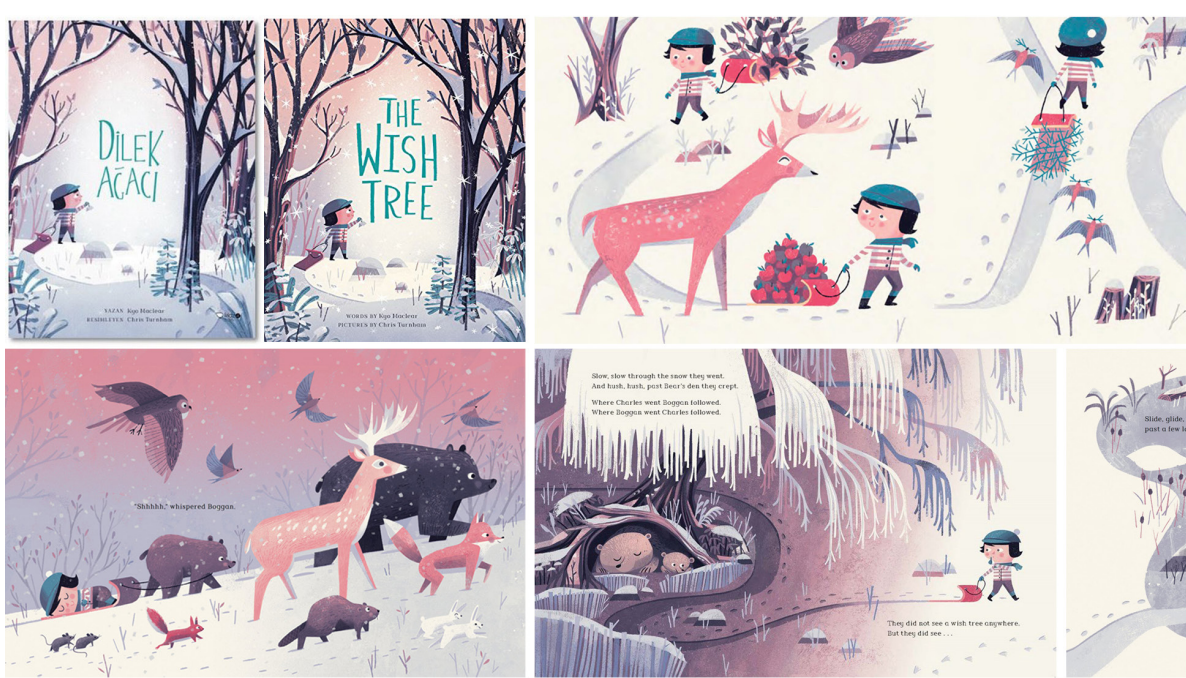

Görsel I.Kyo Maclea rve Chris Turnham, Dilek Ağacı / The Wish Tree, 2020, Resimli Çocuk Kitabı,kapak ve resimlenmiş iç sayfa tasarımı görüntüleri, $22 \times 25,5 \mathrm{~cm}$

Kitapta yardımlaşma, dostluk, sevgi ve umut kavramları dilek ağacına ulaşmak isteyen Umut adlı karakterin macerası ile işlenmektedir. Hikaye kahramanları Umut ve kızağı Karkış, çıktıkları yolculukta karşılarına çıkan farklı türdeki hayvanlara yardım ederek ilerlerler. Resimleme dili, naif kış görüntüsü, çocuğun dikkatini çekici hikayesi, masalsı renk paleti ve iç açıcı dokuları ile izleyicileri içine çekerken, Umut'un hedefine ulaşmasına şahit olduğumuz bir kitaptır. Bu yönüyle, Çer'in (2016: 86) "çocuğun doğasının, bakış açısının, ilgi ve gereksinmesinin, dil ve anlatım evreninin ve algılama düzeyinini kitaba yansıması gerekir" ilkesine uyulduğu gözlenir. Hikayenin temel aldığı yardımlaşma ve umut kavramları, anlatımda bütünlük içerisinde vurgulanmaktadır. Bu anlamda kurgu, Klausmeier'in kavram öğretiminde yedi ilke ile paralel gelişmektedir. Özellikle altıncı aşama olan "...kavramı kullanarak problem çözme denemeleri yapılmalıdır" (Ülgen, 2001: 134) maddesi, hikaye kahramanı Umut'un hedefine ulaşmak için yardımlaşma kavramını sıklıkla kullanıyor olmasıyla ilişkilendirilebilir. Kitap tasarım ilkeleri açısından değerlendirildiğinde, fiziksel, resimleme ve içerik özellikleri, okul öncesi ve 1. sınıflar kategorisinde yer alırken, anlamlı sözcüklerin ve resimlemelerin aynı sayfada kullanılması, yazı karakteri büyüklüğünün 14-16 punto büyüklüğünde ele alınması, iç sayfa tasarımda büyük 
bir bölümünde (3/4 oranında) resimlemenin yer alması, resimlemelerde gerçekçi yaklaşımlarla anlatımı destekleyen açık betimlemelerin yapılması vb. özellikleri nitelikli çocuk kitabı olma özellikleri arasında sıralanabilir. Kitabın kapak tasarımında da hikaye ile ilgili, ilgi çekici bütünsel bir anlatım kurgulanmış, kitabın adı, karakteri, yazarı ve resimleyeni açııından göstergeler net bir şekilde konumlanmıştır.

Çocuk kitaplarında ele alınan bir diğer tema karanlık kavramıdır. Kavrama ilişkin tasarlanmış kitap Görsel 2'de yer alan Orion ve Karanlık / Orion and the Dark adlı çocuk kitabıdır.
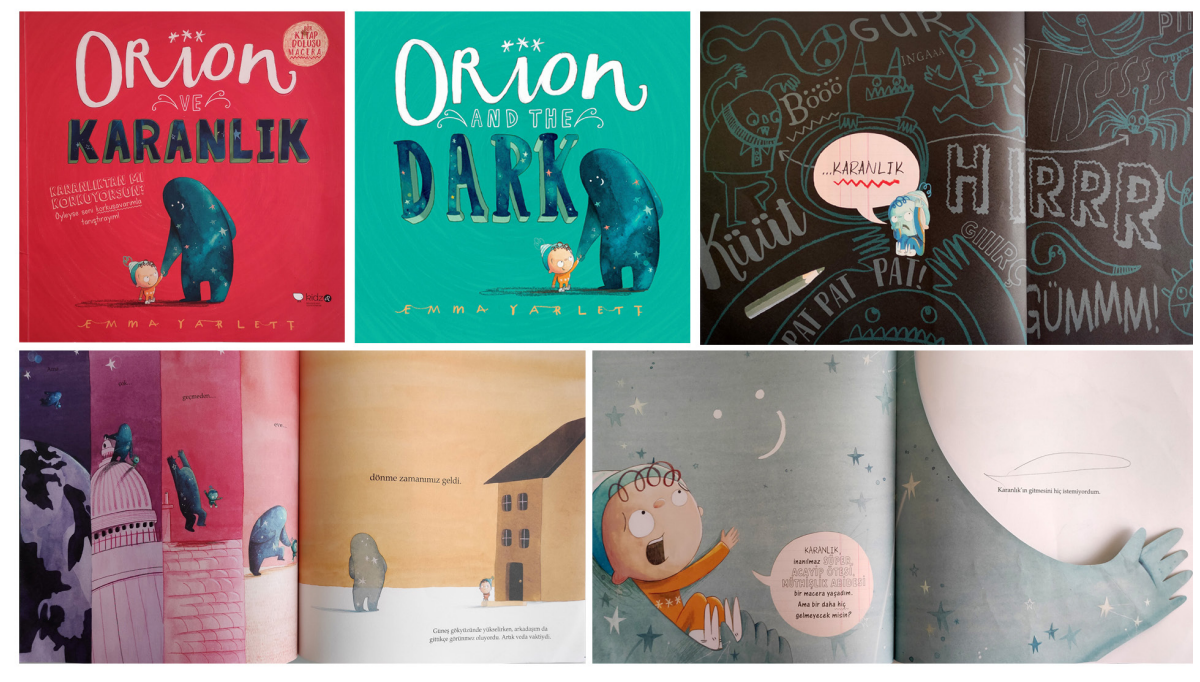

Görsel 2. Emma Yarlett, Orion ve Karanlık / Orion and the Dark,2017, Resimli Çocuk Kitabı, kapak ve resimlenmiş iç sayfa tasarımı görüntüleri, $25,5 \times 26 \mathrm{~cm}$

Yazan ve resimleyen Emma Yarlett, çeviren Zeynep Alparslan olan kitap, Redhouse Kidz Yayınları tarafından basıımış, 25,5 × $26 \mathrm{~cm}$ ebatlarında tasarlanmıştır. Konusu korku, arkadaşlık olarak tanımlanmakta, bir çok şeyin yanı sıra karanlıktan da korkan Orion adlı çocuğun korku kavramının karaktere büründüğü hikayede, korku ile arkadaşlık kurması ve korktuğu şeylerin aslında korkulacak şeyler olmadığını anlaması ve keşfetmesiyle devam etmektedir. Kitabın illüstratörü, Orion'u kişilikleştirilmiş karanlık karakteri ile tanışırmakta, öncelikle "...kavramın bütünlük içinde yeri gösterilmekte" ve "kavram kendi içinde tanımlanmalıdır" (Ülgen, 2001: 134) şeklindeki kavram öğretimi özelliklerini taşır. Biçimsel özellikleri açısında, kitabın büyüklüğü, ilgi çekici kapağı, anlaşııılığı yüksek resimlemeleri, eğlenceli hikaye örüntüsü çocuğa görelik özelliklerine göre işlenmiş, metin- lerin anlamına uygun olarak kullanılması ve anlamlı yazı büyüklüklerinin tercih edilmesi, özel kesim yöntemiyle karanlık karakterinin çocuğa elini uzatması ve iletişim kurması kavramın öğretiminde içeriğin resimleme ve biçim ilişkisi açısından destekleyici ayrıntılarıdır.

Bir diğer kitap ise yazan ve resimleyen Shanon King - Chai olan, 2017 basım tarihli, $26 \times 26 \mathrm{~cm}$ ebatlı, Türkiye İş Bankası Kültür Yayınları tarafından basımı yapılmış Uç Uç Böceği Lusi / Lucy Lady Bird adlı resimli öykü kitabıdır (Görsel 3). Kitapta, hikayenin kahramanı Lusi'nin sırtında hiç benek yoktur ve kardeşleri gibi beneklere sahip olmak ve uçmak ister. Lusi'nin çıktığı yolculukta mevsimleri de şiirsel betimleme ile ele alarak hikayeyi kurgulayan yazar, Lusi'nin farklı dört hayvandan yardımlaşma yoluyla benek alması, renkli benekleri sayesinde kardeşleriyle aynı özelliklere sahip olması ancak kendisine özgü renkleri sebebiyle farklı olduğu mesajı iletilir. Yardımlaşma ve farklı olmak kavramları, hikayenin temasını belirlemiştir.

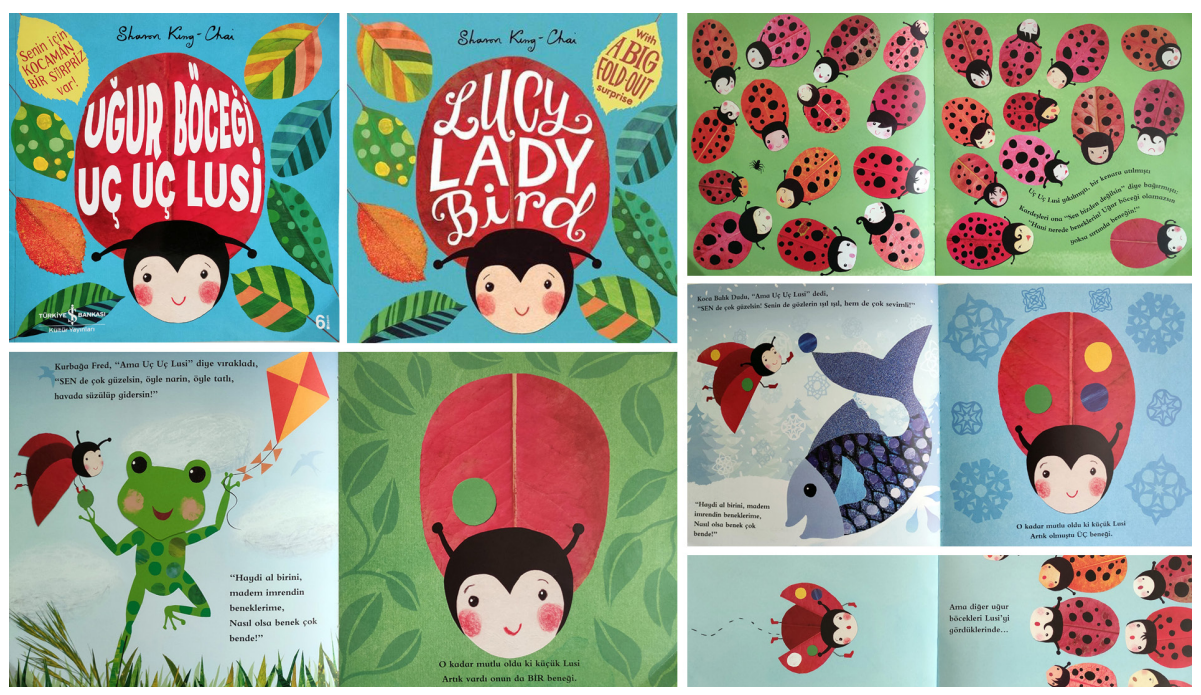

Görsel 3.Sharon King - Chai, Uğur Böceği Uç Uç Lusi / Lucy Lady Bird, 2020, Resimli Çocuk Kitabı, kapak ve resimlenmiş iç sayfa tasarımı görüntüleri, $26 \times 26 \mathrm{~cm}$

Kitap tasarımlarında olması gereken iç yapı ve dış yapı bağlamında içerik ve biçimsel özelliklerin bulunması gerekir. Kapak, sayfa tasarımı (düzeni), boyut, resimleme, yazı karakteri büyüklükleri ve seçimi biçimsel özellikler olarak nitelenir. Çocuğa görelik tanımından hareketle ilgi çekici bir kapak, kitabı okumaya yönlendirecek ve merak uyandıracak bir resimleme ile mümkün olmaktadır. Bu kitapta da ilgi çekici renkler dikkat çekmekte, detaylardan arındııımış anlaşılır resimleme ve betimleme kullanılmaktadır. 
Kitabın ön kapak resimlemesinin kitabın konusuyla ilişkili tasarlanmakta, $1 / 4^{\prime}$ ü yazıya, 3/4' ü resimlemeye ayrılmış, kitaptaki ilgili resimleme ve metinler aynı sayfada yer almakta, resimlemelerde çizgiler net, anlatım gücü yüksek, resimlemeler gerçekçi ve somuttur özellikleri ile resimlendirme özelliği maddelerini taşımaktadır (Gönen, Uludağ, Fındık Tanrıbuyurdu ve Tüfekçi, 2014: 131). Kavram öğretimi aşamalarından, kavramın bütünlük içindeki yeri, kendi içinde tanımlanmakta ve olumlu örneklerle pekiştirilmektedir. Yardımlaşma kavramı, olay örgüsü genelinde hikayeyi sarmaktadır. Sonuca ulaşan Lusi, temayı deneyimlemiş olmaktadır. Öyle ki “...kavramı kullanarak problem çözme denemeleri yapmalıdır" (Ülgen, 2001: 134) ilkesi karşılanmaktadır. Sever(2019: 22), çocukların algısal gelişimine katkı sağlamaları açııından çocuk kitaplarının "...biçimsel ve içerik özellikleriyle, okul öncesi dönemdeki çocukların öncelikle eğlenme-oynama ve bularak (keşfederek) öğrenme gereksinimini karşılamalı, onların algısal gelişimine katkı sağlamalıdır" özelliği taşıması gerektiğinden söz eder. Bu kitapta da Lusi'nin benekleri tamamlama süreci, eğlenceli ve keşfetme yoluyla anlatılmakta, kitabı okuyan çocuk eğlenerek, bularak ve oynayarak öğrenme deneyimi yaşamaktadır.

\section{1. Çocuk Kitaplarında Ölüm Kavramı ve Örnek İncelemeleri}

Ölüm kavramı Türk Dil Kurumu Sözlüğünde yer alan tanımıyla "Bir insan, bir hayvan veya bitkide hayatın tam ve kesin olarak sona ermesi, ahiret yolculuğu, ebedî uyku, emrihak, irtihal, memat, mevt, vefat" olarak tanımlanmaktadır (TDK, 2011: 1847). Çocukların bu kavramı tanımlayabilmeleri ve kabul etmeleri yaş gruplarına göre farklılık gösterebileceği gibi, içerik ve biçim yönünden nitelikli çocuk kitapları ile bu sürecin algılanması desteklenmektedir. Özellikle tanımlanması zor konulardan ölüm kavramının işlendiği çocuk kitapları, çocuğun aile içinden birisini kaybetmesi durumu karssısında ebeveyne ve çocuğa süreci nasıl yönetmeleri konusunda bilgi iletir, kahramanın yerine kendisini koyması sağlanır. Bu konuda çocuk pedegogları, resimli çocuk kitapları içerik geliştirmede etkin rol oynamalı, çocuk psikolojisine uygun hikayenin geliştirilmesi sağlanmalı, resimlemelerde anlatım, çocuğa görelik bağlamında yaş gurubunun algı farkındalığı göz önünde bulundurularak tasarlanmalıdır.

Bu aşamada ölüm kavramını tema olarak işleyen, beş farklı kitap incelenmektedir. Kitap değerlendirmeleri, içerik ve biçim bağlamında resimli kitap özellikleri vurgulanarak ele alınmakta, kavram öğretimi aşamasında etkinliği yorumlanmakta, çocuğa göreliği detaylandırılmakta ve pragmatik anlamda yarar sağlayıp sağlamadığı sorgulanmaktadır. Elde edilen bulgular ve değerlendirmeler, örneklerin incelenmesi aşamasında yer almaktadır. Beş farklı kitap değerlendirmeleri, makalenin yönteminde yer alan aşamalar dikkate alınarak yapılmaktadır. Her bir kitabın ölüm kavramını ele alış şekli, karakter analizi, karakterlerin betimlenmesi, soyut kavramların somutlaştırılarak karakterize edilmesi, resimleme dili farklılığı vb. kavram öğretimi aşamaları da dikkate alınarak incelenmiştir. Çocuk kitaplarında kavram öğretimi, özellikle soyut kavramların ele alınması, çocukların öğretim sürecini destekleyici olmuştur. İncelenen kitaplar aynı yöntemle değerlendirilmiş ve aşağıda sıralanan bulgulara ve çıkarımlara ulaşılmıştır.

Dedemin Adası (Grandad's Island), ölüm kavramını ele alan çocuk kitaplarından biridir (Görsel 4). Sevgi, ölüm, hayat kavramlarının işlendiği, yazar ve resimleyeni Benji Davies olan Dedemin Adası/ Grandad's Island adlı resimli çocuk kitabı, çevirisi Oğuzhan Aydın tarafından yapılmış, Redhouse Kidz Yayınları tarafından basılmıs, 28 × 24,5 cm ebatlarındadır. Kitap, 2015 yılında AOI Uluslararası illüstrasyon Ödülü'ne ve Sainsbury Çocuk Kitabı Ödülü'ne layık bulunmuştur.

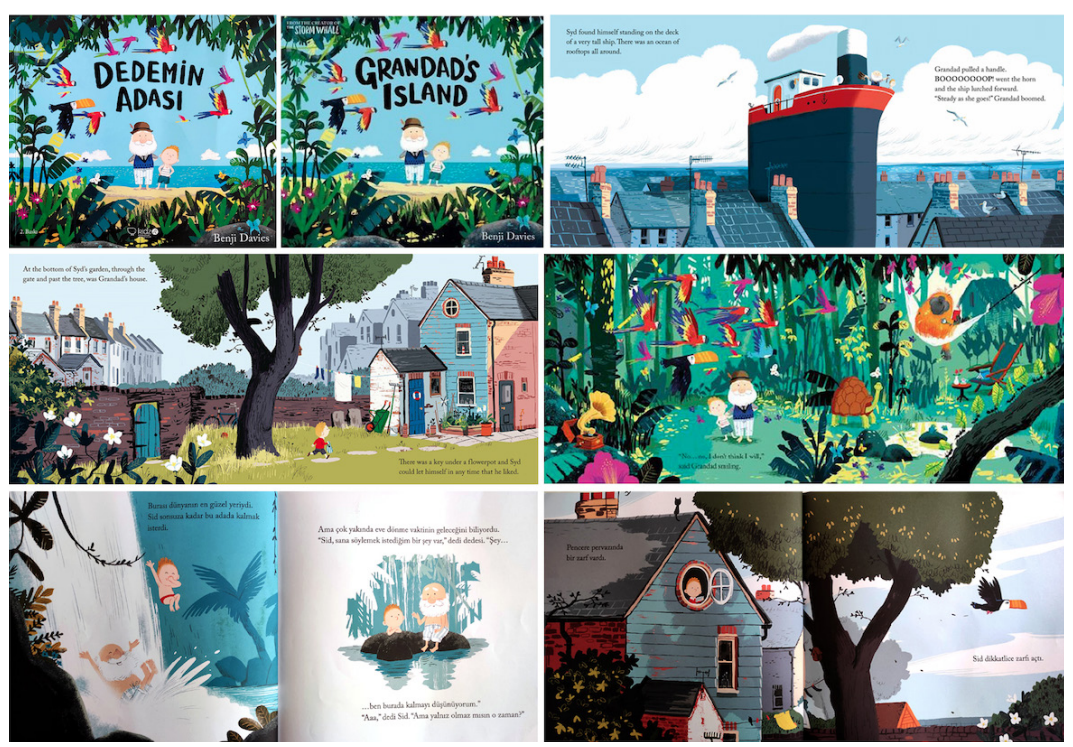

Görsel 4. BenjiDavies, Dedemin Adası / Grandad's Island. 2015, Resimli Çocuk Kitabı, kapak ve resimlenmiş iç sayfa tasarımı görüntüleri, 28 x $24,5 \mathrm{~cm}$

Kitapta Sid adlı küçük bir çocuğun dedesini kaybetmesi, onun anlayacağ ve korku yaşamadan anlamlandırabildiği bir kurguda anlatılmaktadır. Kitapta Sid ile dedesinin sevgi dolu ilişkisi, ölüm kavramının ele alındığı yolculuğa beraber çıkması ile işlenir ve Sid eve dönüş vakti geldiğinde dedesini gittiği yerde bırakır. Gittikleri yerin, kitapta yemyeşil, eğlenceli, huzurlu, 
rengarenk ve farklı türde hayvanlarla dolu bir ada olarak betimlendiği görülür. Klausmeier'in kavram öğretimi aşamalarından kavramı kullanarak problem çözme denemeleri yapılır (Ülgen, 2001: 134).

Kitabın tasarım özelliklerine değinmek gerekirse, boyutu çocuğun el yapısına uygun, ayırt edici bir ölçüde düşünülmüş, kağıt seçiminde gözü yormayan mat kuşe kağıt tercih edilmiştir. Resimleme dilinde, net ve ilgi çekici biçimler geliştirildiği, içerikle uyumlu, merak uyandıran ilgili bir kapak tasarlandığı görülür. Kitapta vurgulanan bi ana fikir, șiirsel bir öykü ile anlatılmaktadır. Birbiriyle ilgili metin ve görsel ögeler birbirlerine yakın sayfalarda yer almaktadır. Bu durum öğrenmeyi destekleyici ilkelerin kullanıldığını desteklemektedir. Metin büyüklükleri okunabilir boyutta yerleştirilmiş, 3/4'lük resimleme alanının olması gözetilmiştir. 4-6 yaş arası cocuklar görselleri artık daha ayrıntılı incelemekte, çünkü bu dönemde dilsel ve bilişsel becerileri gereği resimleme ile farklı boyutta bir ilişki kurmaktadır. Kavram öğretimi aşamalarından anlamı destekleyici hikaye kurgulanmış, büyüleyici, çocukların düş gücünü destekleyici renkler ve nesnelerle zenginleştirilmiş sahneler tasarlanmıştır. Sid, dedesinin gittiği yeri görmüş, gittiği yerde çok mutlu olduğu mesajını almıştır. Resimleme dilinde çocuğa görelik, anlaşııır, eğlenceli ve merak uyandırıcı niteliktedir. Metni tamamlayıcı resimlemeler ilgili sayfalarda yer almakta, yer alan ipuçlarıyla çocuğun hayal güçleri desteklenmektedir. Anlatılan herşeyin resimlemede olmasından öte, anlatılmayan ancak gizli ipuçları barındıran resimlemeler dikkat çekmektedir. Kitabın son sahnesinde, dedesini adada bırakan Sid'e bir mektup ile fotoğraf gelmiştir. Dedesinin gittiği/kaldığı yerde mutlu olduğu mesajı fotoğrafta eğlenceli bir dilde anlatılmıştır.

Ördek, Ölüm ve Lale / Ente, Tod und Tulpe,Alman çocuk yazarı ve çizeri Wolf Erlbruch tarafından yazılan ve resimlenen, orjinal dilinden Türkçe'ye Bahar Siber tarafından çevrilen, iletişim Yayınları ve Hep Kitap Basımevi tarafından basılan Ördek, Ölüm ve Lale adlı resimli çocuk kitabında,ölüm kavramı kitabın kahramanlarından birisi olarak sembolize edilmektedir (Görsel 5).

Kitapta ölüm kavramı, öncelikle ördek ve ölüm karakterinin karşısşması, arkadaşık kurması ve konuşmalarıyla devam eden bir kurguda ilerler. Ölüm ördeği götürmeye gelmiştir ve ördek bu durumu anlamakta ve korkusunu dile getirmektedir. Ancak kurdukları arkadaşıı, ölüm kavramını esprili bir dille yorumlanmasını sağlayan kitapta olağanlaşır. Ölüm ile göle giden Ördek, Ölüm'ü üşüdüğü için ısıtmakta, okuyuculara samimi dostluğa ilişkin mesaj iletilmektedir. Ve sonunda okuyucu hayata veda eden ördeğin hüzünlü sonu ile karşılaşır.

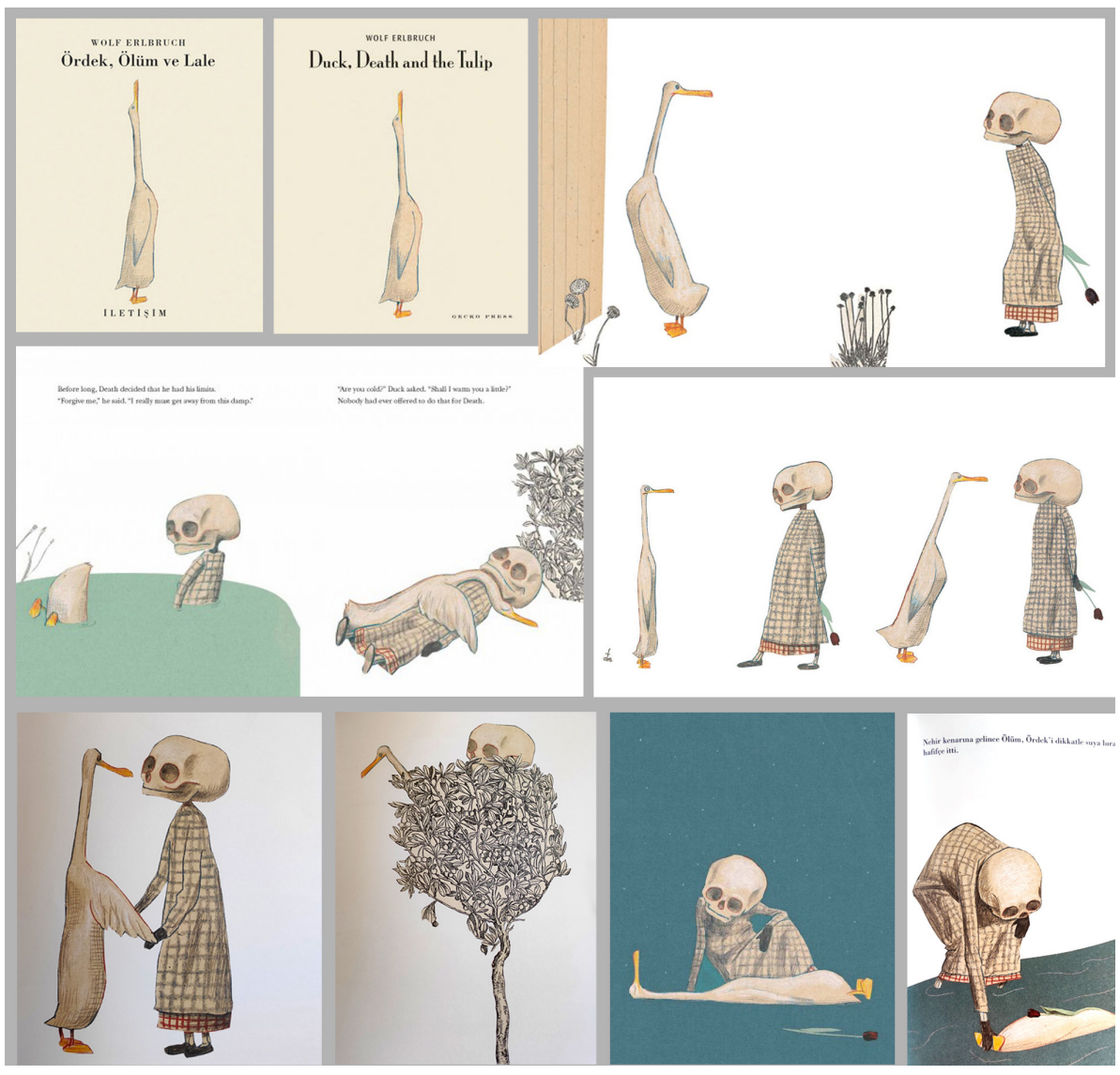

Görsel 5. Wolf Erlbruch, Ördek, Ölüm ve Lale / Ente, Tod und Tulpe,2019, Resimli Çocuk Kitabı, kapak ve resimlenmiş iç sayfa tasarımı görüntüleri, 24 x 29,5 cm.

Hikayenin başında Ölüm, Ördek ile ilk karşılaşmasında arkasında tuttuğu laleyi, ölen ördeğin üzerine bırakarak nehre bırakmaktadır. Lale, sembolik bir anlatımla ölüm kavramını destekleyen öge olarak kullanılmışır. Gösterge ve anlamlama bağlamında lale figürü "uyandırdığı belleksel imge kafamızda başka bir uyarııının imgesine bağlanır" (Guiraud, 2016: 39) sözüyle ele alınacak olursa, ölüm kavramının anlamına çağrışım yapmakta ve güçlendirmektedir. Ölümün gerçekleștiği sahnedeki solmuș ve boynunu eğmiş lale resimlemesi, anlamı destekleyici rolde görülür. Resimlemelerde anlatım ve kavram vurgulanmak için lale figürünün kullanıldığı görülür. Olağanlaştırılan ölüm kavramı, okuyucuya, korkulacak bir şey olmadığı mesajı ile iletilir. Resimlemelerde yalın anlatım dili kullanıldığı görülmekte, aşırı yoğunluktan uzak sayfa tasarımı, mesajı net anlatan resimlemeler ile yer almaktadır. Temanın içeriğine uygun renk paleti, pastel tonlama ve 
yalın ifade kullanılmıştır. Renklerden uzak bir yorumlama ile durgun bir ruh hali desteklenir. Kitap tasarımı 24 × 29,5 cm ebatlarında, karton kapaklıdır. Çocuklar, kitapları okurken öykü kahramanlarıyla ilgilenirler. Ördek, Ölüm ve Lale adlı kitapta da çocuk her iki karakterle de ilgilenmekte ve iletişim kurmaktadır. Kavramın hikayede kendi içinde tanımlandığı ve kavramın özelliklerini kapsayan bir anlatımdan yararlanılarak kavram öğretimi aşamaları desteklenmiş olur (Ülgen, 2001: 134). "Erken çocukluk döneminde çocuğu kitaba çeken ilk uyaran, kitabın görsel dünyası, çocuğa kitabı sevdiren başat öğe de kitabın görsel değeridir" olarak Sever'in de ifade ettiği gibi, çocuk kitabı resimlemelerinde çocuğun algı düzeyine uygun, di gelişimini destekleyecek, bilişsel seviyesi eşiğinde bir resimleme ile çocuğun hayal dünyası zenginleştirilebilir (Sever, 2019: 167). Kitapta da içerik ile biçim ilişkisinin ortak bir dil ile yorumlandığı söylenebilir.

Annem Her Yerde / Overal en Ergens adlı çocuk kitabı ise, ölüm kavramını şiirsel ve duygusal bir hikaye ile anlatan 5 yaş ve üzeri çocuklara yönelik, yazarı Pimm van Hest, resimleyen Sassafras De Bruyn olan, 2015 yılında Amerika'da, 2016 ve 2020 yıllarında da Türkiye'de Öznel Akdik İşli tarafından çevrilen Gergedan Yayınları tarafından basılan bir kitaptır. 25 x $26 \mathrm{~cm}$ ebatlarında tasarlanmıştır. Hikayede Yolanda adlı küçük kız annesini kaybetmiş, yokluğunu sorgulamakta, çevresindeki her yerde annesini aramaktadır. Sorduğu sorulara bulduğu cevaplarda annesini bulmaktadır. Özellikle 4-6 yaş dönemindeki çocukların kitapta ilgisini kahramanlar çekmektedir. Çocuk bu dönemde karakter ile özdeșim kurmakta, karakter de çocuğun hikaye içinde olmasını sağlayıp yaşamını destekleyici konusu ile ilgisini çekebilmelidir. Annem Her Yerde adlı çocuk kitabında da Yolanda adl küçük kız çocuğu ve annesinin yokluğu (ölüm kavramı), çocuğun bilişsel ve duyuşsal yeterliliği göz önünde bulundurularak hikayeleștirilmektedir. Kitapta Yolanda, annesine yakın baska kahramanlarla da iletişim kurmakta, böylece hikayeyi tamamlayacak yardımcı ögelerden yararlanılmaktadır. Anlatıda çocukların sosyal hayatına girip bir çok noktadan onları yakalayabilmek için uğraşıldığı görülür. Kavram öğretimi aşamalarından, kavramı kullanarak problem çözme denemeleri yapılmaktadır.

Biçimsel özellikleri değerlendirilecek olursa, karşılıklı sayfa tasarımlarında anlatının vurgulanması ve desteklenmesi için ilgili resimleme kullanıldığı görülür. Duygusal hikayesi, çizerin renk paletini etkilemiş, gereksiz ayrıntılardan uzak, yalın bir anlatımla öğretim gerçekleştirilmektedir. Ölüm kavramı, çocuğa şiirsel bir dille anlatılan hikayede duyumsatımaktadır. Bu dönemde çocuklara "...iletilerin doğrudan değil duyumsatıı bir biçimde verilmesi gerekir" (Çer, 2016: 164).

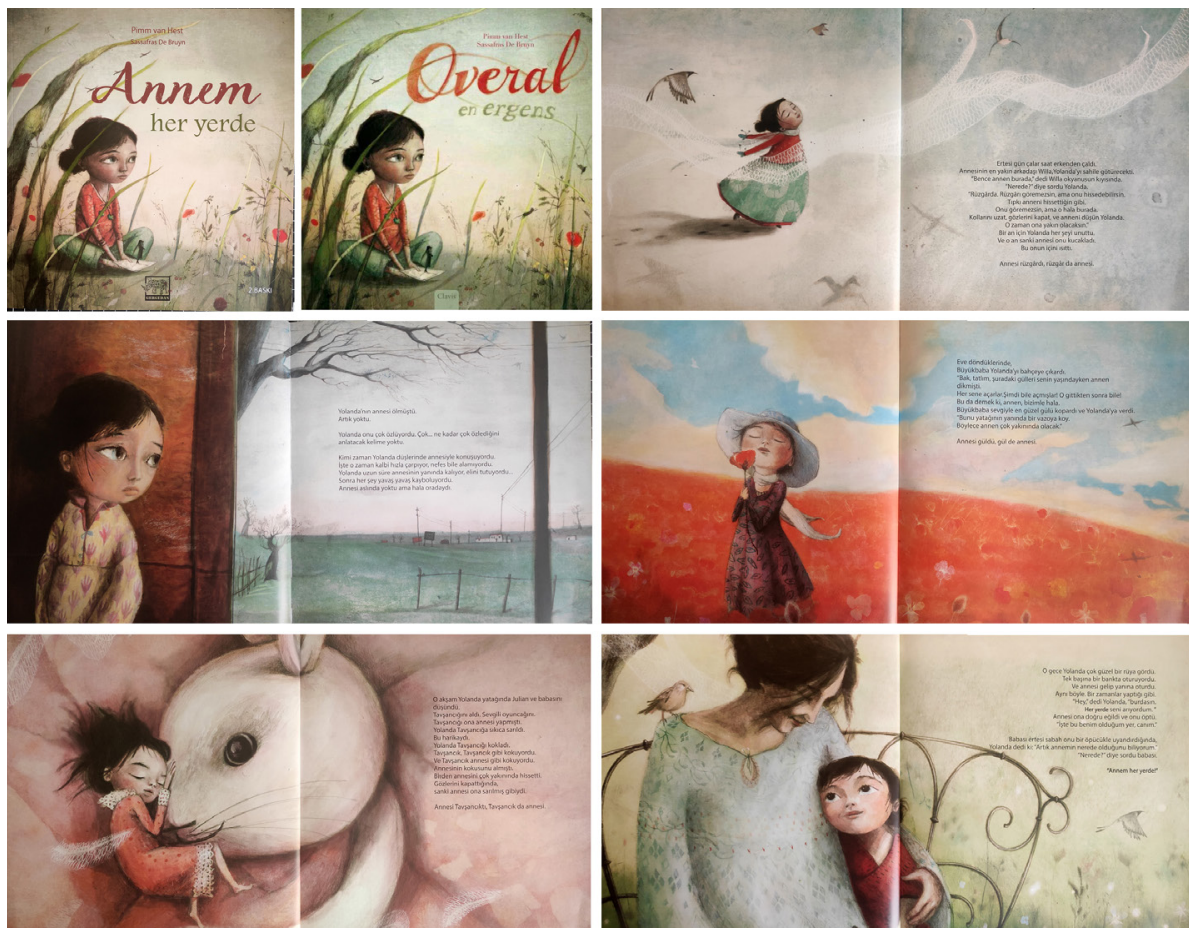

Görsel 6.Pimm van Hest ve Sassafras De Bruyn, Annem Her Yerde / Overal en Ergens. 2020, Resimli Çocuk Kitabı, kapak ve resimlenmiş iç sayfa tasarımı görüntüleri, 25 × 26 $\mathrm{cm}$

Çocuğun bilişsel ve duyuşsal gelişimi de göz önünde bulundurularak kavram hikaye geneline islenerek yorumlanır. Yolanda, sakin, durgun, hüzünlü, ve sorgulayıcı bir şekilde biçimlendirilmiştir. Resimlemeler, metnin anlamını tamamlama ve sözcüklerle anlatılmayanları da içerisinde barındırma özellikleri sebebiyle çocukların ilgisini çeken tasarım ögeleri olmuştur. Sever'in ifadesiyle resimlemelerde "metne yeni anlamlar katan estetik uyaran olma" özelliği rastlanmaktadır (2019: 166).

Kitap tasarımında ilgi çekici bir kapak resimlemesi ve içerikle bütünlük kuran bir yorumlama dikkat çeker. Yazı büyüklüklerinin okul öncesi dönem olan $0-6$ yas ve 7 yaş için uygun 24-22-20 punto aralığı dikkat edilerek tasarlandığı, ilgili resimlemeler metinle yanı sayfada yerleştirilmiş olduğu görülür. Resimlemelerde çocuğun hayal gücünü tamamlayacak ayrıntılar hissedilir. Çocuğu çok yönlü düşünmeye sevk ettiği, farklı nesneler kullanarak annesini bulması ve hissetmesini sağladığı dikkat çeker. $3 / 4$ 'ü resimleme olan karşılıklı sayfa tasarımlarında, görsel iletişım ögesi daha baskın 
kullanılmış, metinsel ögelerin resimlemeyi destekleyici nitelikte sözcükler içerdiği görülür.

Elveda Bay Muffin / Adjö, herr Muffin adlı çocuk kitabı, Ulf Nilsson ve Anna-Clara Tidholm tarafından yazılan, Anna-Clara Tidholm tarafından resimlenen, Türkçe'ye Ali Arda tarafından çevrilmiş ve birçok dile çevrilen, 2017 yılında da Can Sanat Yayınları tarafından basılmış bir çocuk kitabıdır. $21,5 \times 21,5 \mathrm{~cm}$ ebatlarında, sert karton kapaklıdır. Kitapta hikayenin karakteri Bay Muffin, yașlanmıs bir kobay fare olarak tasarlanmıștır. Kitap, 2002 yılında İşveç'te August Ödülü'ne layık görülmüştür. Hikayede Bay Muffin'in hayatını hatırladığı, mutlu günlerini okuyucu ile paylaştığı sahneler yer alır. Yaşadığı mavi evde, önceden kaybettiği eşi ve altı çocuğunu düşünmekte, mutlu günleri olduğunu hatırlamaktadır. Bir gün zaman onun için de son bulacak, sevenleri onu hep güzel hatırlayacaktır. Resimlemelerde Muffin'in ölümünden sonraki onun adına yapılan paylaşımlar ile kavram ayrıntılandırımaktadır. Resimlemelerde kullanılan yalın, hikayeye uygun dokunaklı renkler dikkat çeker. Her sayfada ayrı resim ve yazı olduğu görülür. 6 yaş ve üzeri çocuklar için tasarlanan hikaye ve kitap, bu dönemde artık kavramları büyük ve küçüklükleri, uzun ve kısalıkları ayırt edebilen bir hedef kitleye hitap eder. Bu nedenle de kullanılan yazı büyüklüğü ve sıklı̆̆ı, yas aralı̆̆ı daha küçük çocuklar olan kitaplara göre daha küçük ve sık kullanılmıştır. Kapak tasarımı ve resimleme ile içerik bütünlüğü ve devamlılığı vardır. Ufka doğru bakan Muffin, aslında okuyucuyu da baktığı yere sürükler.

Tema, Muffin'in baktığı yönde şekillenir. Çer (2016: 164), bu dönemdeki çocuklara yazılan kitaplarla ilgili olarak yazınsal nitelikteki kitapların "... hiçbir biçimde çocuklara öğretici ya da belletici bir anlayışla, bir düşüncenin ya da söylemin taşıyııııı̆ıını yapmamalıdır. Çünkü yazınsal nitelikli kitapların başat amacı, insana, yaşama ve doğaya yönelik duyarlılık olusturmaktır" özelliğine dikkat çeker. Bay Muffin'de de ölüm kavramı, bir bitiş olmaktan ziyade doğum, yaşam ve ölüm üçgeninde bir sürecin temsiliyetidir. İlgili metinlerin resimlemelerde yakın konumlandırıldığı görülür. Dokunaklı hikayesiyle çocuğa her canlının, doğup, yaşayıp, yaşlanıp öleceği mesajı iletilir.

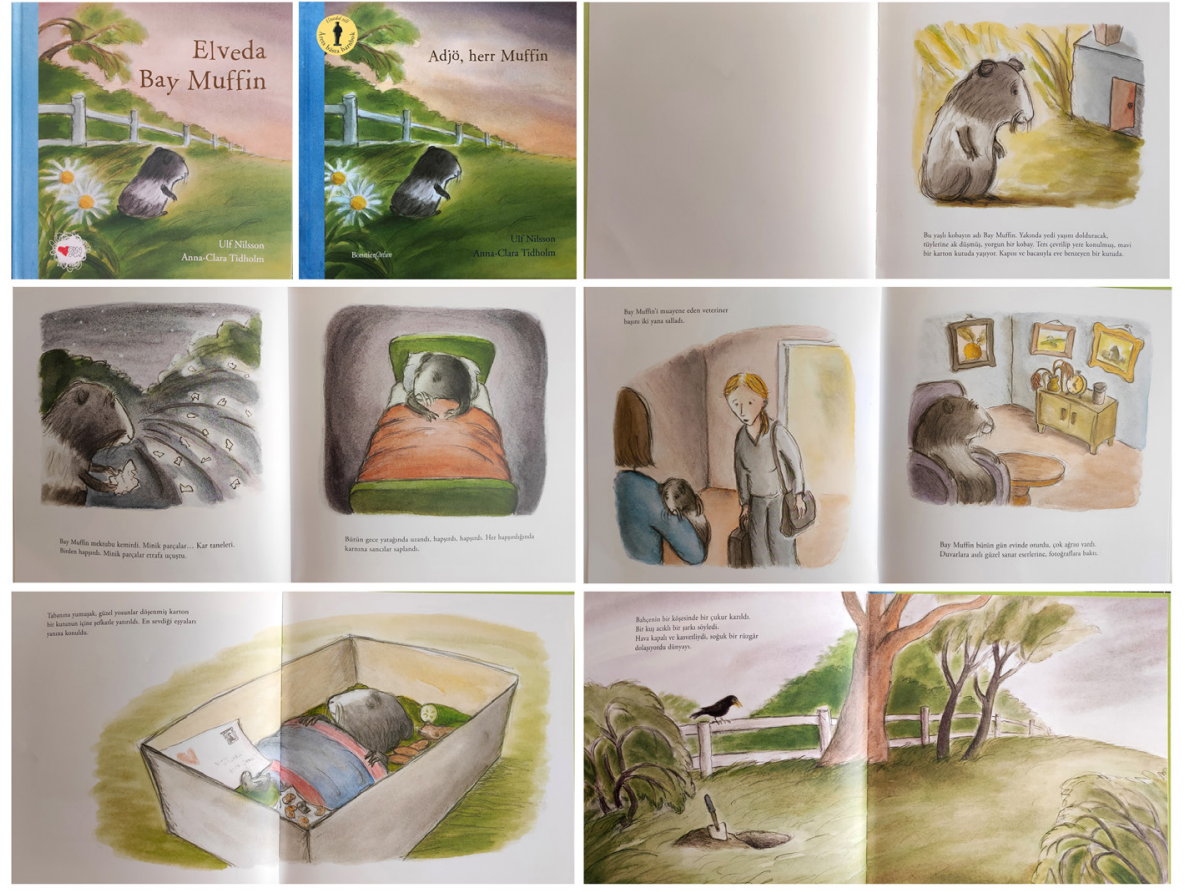

Görsel 7. Ulf Nilsson ve Anna-Clara Tidholm, Elveda Bay Muffin / Adjö, herr Muffin. 2017, Resimli Çocuk Kitabı, kapak ve resimlenmiş iç sayfa tasarımı görüntüleri, 21,5 × $2 I, 5 \mathrm{~cm}$

Eski Dostum Lodos / My Old Pal, Oscar, yazarı Amy Hest, resimleyen Amy Bates olan, Türkçe'ye Sedef Özge tarafından çevrilen, ilk 2016 yılında basılan ve 2018 yılında da KVA Çocuk Yayınları tarafından basılan, $24 \times 24$, 5 ebatında sert karton kapaklı bir çocuk kitabıdır. 5 yas ve üzeri çocuklar için tasarlanmış, tematik olarak, ölüm, kaybetme korkusu ve hayvan sevgisi içeriği ile temellenmiştir. Özellikle çocukların kaybettikleri oyuncağınınya da sevdiği bir arkadaşının yerine birisini kabullenmesi zordur. Sevdiklerini kaybetmek çocuk için kolaylıkla tanımlanan ve atlatılan bir durum değildir. Hikayede sevdiği köpeğini kaybeden çocuk baş kahramandır. Köpeğinin yokluğu karşııında yerine başka hiçbir hayvanı koymak istemez. Bu durum küçük sevimli bir köpeğin onunla tanışmak ve dost olmak istemesine kadar sürer. Uzun bir süre köpeği yakınına yaklaştırmaz. Kavram öğretimi aşamalarından kavram kullanılarak problem çözme denemeleri yapılır. Kaybedilen köpeğin yerine yeni bir köpek koyularak hayvan sevgisi kavramı pekiştirilir. Hikayenin sonunda Lodos'un yerine yeni köpeği koyan, bu şekilde üzüntüsüyle başa çıkan çocuk işlenmiştir 


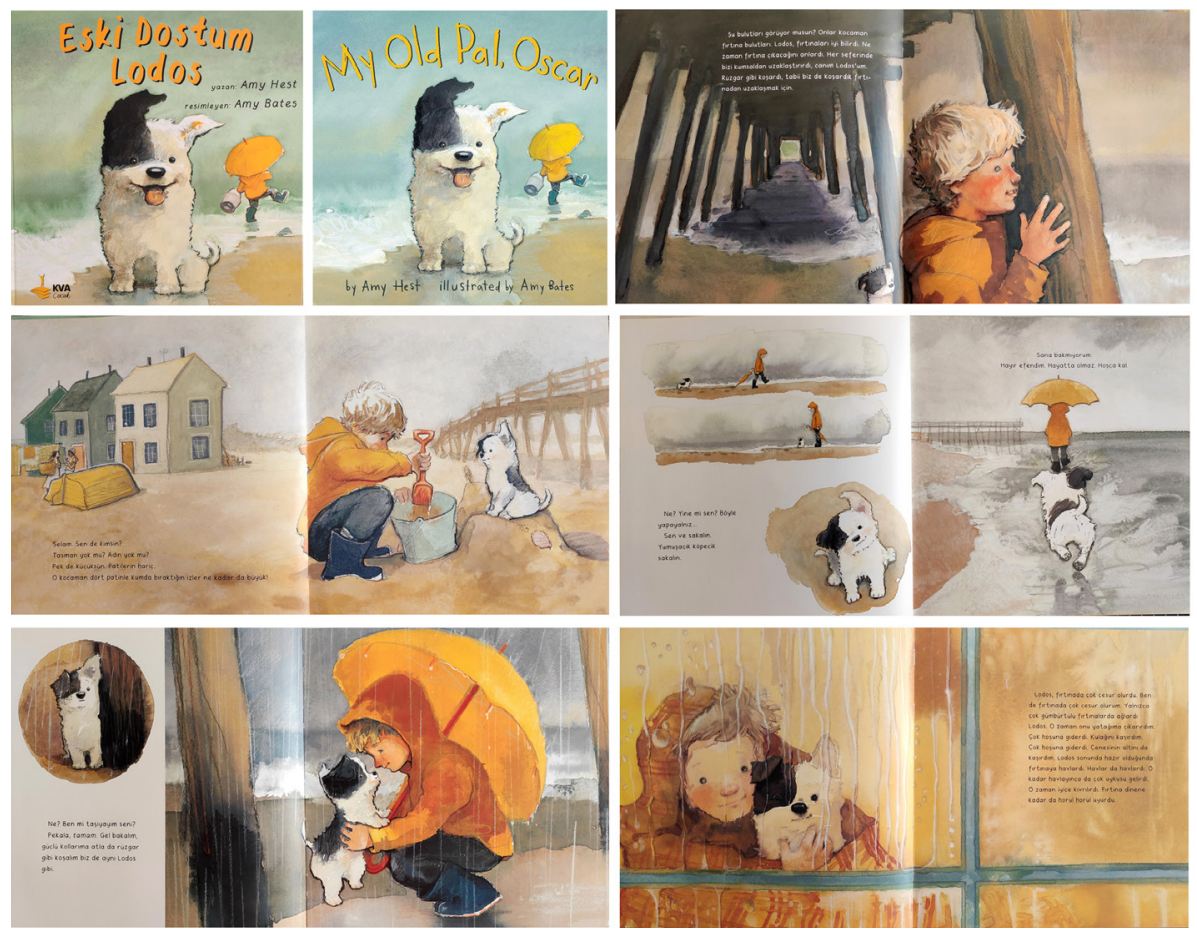

Görsel 8. Amy Hest ve Amy Bates, Eski Dostum Lodos / My Old Pal, 2016, Resimli Çocuk Kitabı, kapak ve resimlenmiş iç sayfa tasarımı görüntüleri, 24 × $24,5 \mathrm{~cm}$

Kitapta kullanılan resimleme ve tasarım özelliklerine değinilecek olursa, 5 yaş ve üzeri için çocuklara hitap edilen bir dil kullanılmış, yazı büyüklükleri 20-22 punto aralığında tasarlanmış, resimlemeleri destekleyici metinler karşııklı sayfada konumlanmıştır. İçerikle uyumlu ve anlamı pekiştiren büyüklükte yazılar metin içerisinde kullanılmıştır. "Gümbür! Çatırt! Gümbür!" kelimelerinin hikayede gök gürlediği sahnede büyük yazı karakteriyle kullanılması bu duruma örnek verilebilir. 3/4'lük alanda resimleme $1 / 4$ 'lük alanda ise metinsel öge yer almakta, böylelikle 5 yaş ve üzeri çocuklar için resim ve metin büyüklüklerinin uygun bir ölçülendirme ile tasarlandığı söylenebilir. Genel olarak resimlemelerde atmosfere uygun renkler kullanılmış, çocuğun köpek ile iletişim kurduğu ve yakınlaştıkları sahnelerde sıcak renklerin tercih edilerek anlatımın desteklendiği görülür. Kitap kapağında yer alan köpek, çocuğun kaybettiği arkadaşı Lodos değil, onun yerine koyduğu köpektir. Bu durum kitabı henüz okumayan okuyucu için şaşırtıcı olmaktadır. Mesaj aslında kitap kapağında da mevcuttur. Kitabın arka kapak yazısındaolduğu gibi "sevdiklerimizi kaybettiğimizde onlara duyduğumuz özlem, sevgimizi paylaşarak üzüntümüzün üstesinden gelmek ve hayata devam etmek" olarak yorumlanabilir (Hest ve Bates,2016).

\section{Sonuç}

Resimli çocuk kitapları, çocukları bilişsel gelişimlerini destekleyen, onları hayata hazırlayan, hayal güçlerini destekleyici ipuçları barındıran, keyifli vakit geçirirken öğreten kaynaklar olarak tanımlanır. Bütünsel anlamda bakıldığında "diğer edebi türlerde olduğu gibi resimli kitap formatı da edebi unsur olan karakter, olay örgüsü, mekan, bakış açısı, üslup ve temayı göz önünde bulundurur. Bunların üstüne eklenen çizimlerin etkisi, sözcüklerin bu alanları bütünüyle geliştiremeyeceği anlamına gelmektedir" (Lukens, Smith ve Coffel,2018: 53) ifadesi ile çocuk kitaplarındaki resimlemelerin anlatının ötesinde anlatımı güçlendirdiği ve çok yönlü düşünmeye teşvik ettiğinden söz edilebilir. Öyle ki resimli çocuk kitabında resimlemeleri okumak, metinleri okumaktan daha uzun bir sürede gerçekleşir. Temaya uygun belirli bir anlamın elde edilebilmesi için resimleme ve yazınsal ögenin birlikteliği önemli olmaktadır. Keza anlatılması, öğretilmesi ve deneyimlenmesi zor olan ölüm kavramını tematik olarak işleyen çocuk kitaplarında, yazım dilinin didaktik olmayan bir üslupla geliştirilmesi, çocuk psikolojisini temel alan yorumlamayla kurgu çocuğa görelik bağlamında ele alınması ve yas aralığına uygun bir resimleme diliyle karakter ve sahneler resimlenmesi önerilmektedir. Çoklu ortam tasarım ilkeleri gereği, birbirleriyle yakın anlamlı olan görsel ve metinsel ögenin yakın sayfada bir arada kullanılmasıyla öğrenme etkin bir şekilde gerçekleşmektedir. Öyle ki resimli çocuk kitaplarında da konudan uzaklaștıracak ayrıntılara ve görsellere yer verilmemesi, metin ile ilgisi olmayan resimlemelerin kullanılmaması, konunun daha kısa sürede ve etkin olarak anlaşılmasını sağlamaktadır. Bu makale kapsamında ölüm kavramının tematik olarak işlendiği çocuk kitapları incelenirken; kavram öğretimi, resimleme farklılıkları, çocuğa görelik bağlamında değerlendirilmekte, soyut kavramların resimlemelerle öğrenilmesinin daha kolay hale getirildiği, yardımcı ögelerle anlamın pekiştirildiği gözlenmekte, kitap kapağının, boyutunun ve yazı büyüklüklerinin bu süreçte çocukların fiziksel yeterliliklerine göre ölçülendirilmesi gerektiği düşünülmektedir.

Çocukların yaşamı, ölümü vb. soyut kavramları içeren dünyayı kavramaları, Piaget'in ifadesiyle bilincin 'şeylere' atfedilmesiyle ilişkili olarak dört aşamada gelişir. Birinci aşamada her şey, faaliyete veya bir işleve veya herhangi bir kullanıma sahip olan yaşam olarak kabul edilir. İkinci aşamada yaşam, hareketle tanımlanır, tüm hareketler belirli bir dereceye kadar kendiliğinden olarak kabul edilir. Diğer bir aşamada ise çocuk kendiliğinden hareketi, dıs etken tarafından aktarılan hareketten ayırır ve yaşam, birincisi ile özdeşleşir (Piaget, 1929: 194, 195). Bu durumda çocukların bilinç akışını 
dış etkenlerin etkilediği ve yaşam olgusunu geliştirmelerinde karşılaşılan, görülen, duyulan vb. eylemlerin algıyı yönlendirdiğgi söylenebilir. Ölüm kavramının incelenmesinde de, yaşanılan, kaybedilen ve böylelikle sorgulanan yokluk kavramı, hikayeleştirilerek ve kavram öğretme stratejisine göre sonuca ulaşmak üzere problem çözerek pekiştirilmektedir. Ölümün, yaşam içerisinde olağan bir kavram olduğu, soru ve cevaplarla desteklenerek, hikayesel anlatımla çocuğa aktarırır. Çocuk ve ebeveyn arasında kurulan etkili iletişim yolu olan kitap okumak eylemi, farklı temalarla çeşitlenmekte, ebeveyn için her koşulda sürecin yönetimine yardımcı olduğu söylenebilir.

Sonuç olarak, çocukların bedensel ve bilişsel gelişim özellikleri göz önünde bulundurularak hazırlanan çocuk kitap tasarımı ve resimlemelerinin çocuklarda zihinsel imge geliştirmek, bilişsel gruplandırma ve sınıflandırma gibi kavram geliştirme süreçlerini desteklemek gibi bazı davranışları kazanmalarında etken olduğu düşünülmektedir. Bu nedenle çocuk kitaplarının ve resimlemelerin çocukların bilişsel gelişimlerine etkisinin kaçınılmaz olduğu söylenebilmektedir. Kavram öğretim temelli resimli çocuk kitapları, çocukların dış dünyayı kavramalarını ve olaylar arasında ilişki kurabilmelerini kolaylaştırmakta, hikaye kahramanlarıyla kendilerini ve çevrelerini özdeşdirebildikleri ve böylelikle problemleri doğru anlatımla sorgulayan ve çözüm bulan kitaplar aracılığılla kavramı çözümleyebildikleri görülmektedir Bu bağlamda, çocuk kitaplarında tematik olarak işlenen konuların seçimi ve yazımında çocuk psikolojisi göz önünde bulundurulacak şekilde pedagojik uygunluğunun değerlendirilmesinin önemi açıktır. Metinsel içerik ve resimlemelerde bütünlük sağlamak iletinin/anlamın anlaşımasını kolaylaştıracaktır. Bu sebeple resimleyen ve yazan işbirliği, çocuk kitaplarının üretim sürecinde önemlidir. Çocukların algı duyarlııkları ve zihinsel farkındalıkları yaş aralıklarına göre farklılaşmaktadır. Farklı yaştaki çocukların aynı konuyu/kavramı kavraması değişkenlik göstermektedir. Temanın, çocuğun zihninde bir karmaşa yaratmadan aktarılması bu açıdan önemlidir. Bu nedenle belirli yaş aralığına uygun olarak hazırlanan çocuk kitabı resimlemelerinde, yalınlık, anlaşılırlık, daha fazla ipucu ve dikkat gerektirecek detaylandırmalar, renk kullanımı ve gerçekçi üslup değişkenliği söz konusu hedef kitlenin yas aralığına uyumlu olarak planlanmasının önemi, kavram öğretim stratejisi bağlamında ele alınan kavram ve konunun işlenişinde öğretenin belli aşamaları göz önünde bulundurarak içeriği olușturmasının gerekliliği, çocuğa görelik kavramının resimlemelerde göz önünde bulundurulması, içerik ve biçim değerlendirmesi aşamasında tasarım ilkelerinin göz önünde bulundurulması gerekliliği üzerinde durulması gereken konular olduğu sonucuna varılmaktadır.

Bu bağlamda ülkemizde de çocukların bedensel ve zihinsel gelişim evrele- rini tamamlayıcı kavram içerikli kitaplar gözlenmektedir. Bazı kavramların çocuklara yönelik sanatsal bir ifadesi olarak tanımının yapılabileceği ve eğitim amacı taşımayan söz konusu kavram temalı kitapların sayıca artmas yönünde çalışmaların desteklenmesi gerekli bulunmaktadır. Tanımlanması zor soyut kavramları ele alan, resimlemeleriyle çocuğun hayal dünyasın zenginleştiren ve çok yönlü düşünmeye teşvik eden, kavram öğretimi aşamaları göz önünde bulundurularak konuyu işleyen nitelikli kitapların farklı alan uzmanlarıyla alanlarında yetkin kişilerce planlanması, resimlenmesi ve tasarlanması önerilmektedir. 


\section{Kaynakça}

Cüceloğlu, D. (2002). İletişim Donanımları. İstanbul: Remzi Kitabevi.

Cüceloğlu, D. (20।3). Insan ve Davranışı Psikolojinin Temel Kavramları. (27. Baskı). İstanbul: Remzi Kitabevi.

Çer, E. (20।6). Çocuk Edebiyatı 0-6 Yaş Çocuk Kitaplarında Çocuk Gerçekliği ve Çocuğa Görelik.Ankara: Eğiten Kitap Yayıncılık.

Erkmen, N. (1996). Çağdaş Bir Ders Kitabı Nasıl Olmalı? Ders Kitabını Mükemmel Yapan Nitelikler. H. Coşkun., I. Kaya., J. Kuglin. (Ed.). Türkiye ve Almanya'da İlköğretim Ders Kitapları. s. 37-46. Ankara: Bizim Büro Basımevi.

Ertan, G. ve Sansarcı, E. (20I6). Görsel Sanatlarda Anlam ve Algı. İstanbul: Alternatif Yayıncılık.

Guiraud, P. (20|6). Göstergebilim.(3. Baskı). Ankara: İmge Kitabevi.

Hest, A. ve Bates, A. (2016). Eski Dostum Lodos. İstanbul: Kva Çocuk Yayınları.

Hulse, S. H., Deese, J. E. ve Egeth, H. (1975). The Educational Psychology of Learning. USA: McGrow Hill.

Karataş Coşkun, M. (20 I I). Kavram Öğretimi. Adana: Karahan Kitabevi.

Lukens, R.., Smith, J. J. ve Coffel, C. M. (2018). Çocuk Edebiyatına Eleştirel Bir Bakış. İstanbul: Erdem Yayınları.

Male, A. (2017). Illustration A Theoretical and Contextual Perspective. (2. Ed.). New York: Bloomsbury Visual Arts.

Oskay, Ü. (200I). Illetişimin Abc'si. İstanbul: Der Yayınevi.

Senemoğlu, N. (20|8). Gelişim, Öğrenme ve Öğretim Kuramdan Uygulamaya. (26. Baskı). Ankara: Anı Yayıncılık.

Sever, S. (2019). Çocuk ve Edebiyat. (I0. Baskı). İzmir: Tudem Yayıncılık.
Türk Dil Kurumu. (20II). Türkçe Sözlük. (II. Baskı). Ankara: Türk Dil Kurumu Yayınları.

Ülgen, G. (200I). Kavram Geliştirme. (3. Baskı). Ankara Pegem A Yayınları.

Yükselen, A. İ. (2019). Yaş Gruplarına Göre Çocuk Kitapları. M. Gönen (Ed.). Erken Çocukluk Döneminde Çocuk Edebiyatı, s. 57-75. Ankara: Eğiten Kitap Yayınları.

\section{Internet Kaynakları}

Internet: Gönen, M., Uludağ, G., Fındık Tanrıbuyurdu, E. ve Tüfekçi, E. (20 I4). 0-3 Yaş Çocuklarına Yönelik Resimli Çocuk Kitaplarının Özelliklerinin İncelenmesi. Hacettepe Üniversitesi Eğitim Fakültesi Dergisi. 29 (I), s. 126 - 139. Web:http://www.efdergi. hacettepe.edu.tr/yonetim/icerik/makaleler/1959-published.pdf adresinden 14 Aralık 2020'de alınmıştır.

Internet: Piaget, J. (1929). The child's conception of the world. London: Redwood Press Limited. Web: https://archive.org/details/childsconception0 I piag adresinden 09 Ekim 2020'de alınmıştır.

\section{Görsel Kaynakları}

Görsel I. Maclear, Kyo., Turnham, Chris. (2020). Dilek Ağacı / The Wish Tree. (4. Baskı). Redhouse Kidz Çocuk Kitapları. İstanbul: Sev Yayıncılık, s. I2-I3, 20-2I, 24-25.

Görsel 2. Yarlett, Emma. (20I7). Orion ve Karanlık / Orion and the Dark. Redhouse Kids Yayınları, İstanbul: Sev Yayıncılık, s. 4-5, 26-27, 28-29.

Görsel 3. Sharon King - Chai. (2020). Uğur Böceği Uç Uç Lusi / Lucy Lady Bird. (6. Baskı). İstanbul: Türkiye İş Bankası Kültür Yayınları, s. 3-4, 7-8, I4-15, 24-25.

Görsel 4. Davies, Benji. (2015). Dedemin Adası / Grandad's Island. İstanbul: Redhouse Kidz Çocuk Kitapları, s. 4-5, I0-II, 20-2I, 22-23, 30-31.

Görsel 5. Erlbruch, Wolf. (2019). Ördek, Ölüm ve Lale / Ente, Tod und Tulpe. İstanbul: Hep Kitap Yayınları, s. 2-3, 4-5, I0-II, 19, 23, 25, 27. 
Görsel 6. Hest, Pimm van., Bruyn, Sassafras De. (2020). Annem Her Yerde / Overal en Ergens. İstanbul: Gergedan Yayınları, s. 2-3, I0-II, I8-19, 20-21, 24-25.

Görsel 7. Nilsson, Ulf., Tidholm, Anna-Clara. (2017). Elveda Bay Muffin / Adjö, herr Muffin. İstanbul: Can Çocuk Yayınları, s. 3, 20-21, 28-29, 36-37, 38-39.

Görsel 8. Hest, Amy., Bates, Amy. (2016). Eski Dostum Lodos / My Old Pal, Oscar. İstanbul: KVA Çocuk Yayınları, s. 8-9, I2-13, 20-21, 24-25, 28-29 